\title{
Influence of Chicken Manure on Growth and Yield of Forage Sorghum (Sorghum Bicolor L.Moench )
}

\author{
Feisal M. Ismaeil ${ }^{1}$, Awad O. Abusuwar², Ahmed M. El Naim ${ }^{1, *}$ \\ ${ }^{1}$ Department of Crop science, Faculty of Natural Resources and Environmental Studies, University of Kordofan, Elobeid, Sudan \\ ${ }^{2}$ Department of Agronomy, Faculty of Agriculture, University of Khartoum, Shambat, Sudan
}

\begin{abstract}
The increasingly demand of chicken meat in Sudan has prompted more poultry farming with consequent effects on increased utilization of organic wastes (e.g. chicken manure) as fertilizers. Organic wastes contain varying amounts of water, mineral nutrients and organic matter. While the use of organic wastes as manure has been in practice for centuries world-wide. A field experiment was conducted at the Experimental Farm of the Faculty of Agriculture, University of Khartoum, Shambat during the period (February - May 2007) to study the effect of different rates of chicken manure on growth and forage yield of sorghum (Sorghum bicolor (L.), Moench). The treatments consisted of four levels of chicken manure; 0, 1.2, 2.5 and 5.0 tons/ha. The treatments were arranged in a Randomized Complete Block Design in four replicates. The character studies were plant population, plant height, number of leaves per plant, stem diameter, leaf area index, and fresh and dry forage yield. The results showed that there were significant differences among treatments in most parameters during the growing period for growth attributes under study. Chicken manure resulted in an increase in growth attributes as well as forage yield. Chicken manure ( 5 tons/ha) produced higher fresh and dry forage at harvest than the other treatments.
\end{abstract}

Keywords Organic Fertilizer, Fodder Crop, Sorghum, Manure

\section{Introduction}

The use of inorganic fertilizer has not been helpful under intensive agriculture because it is often associated with reduced crop yield, soil acidity and nutrient imbalance (Obi and Ebo, 1995; Ojeniyi, 2000; Ayoola, O. T. and Adeniyan, 2008). Soil degradation which is brought about by loss of organic matter accompanying continuous cropping becomes aggravated when inorganic fertilizers are applied repeatedly. This is because crop response to applied fertilizer depends on soil organic matter (Agboola and Omueti, 1982). The quantity of soil organic matter in the soil has been found to depend on the quantity of organic material which can be introduced into the soil either by natural returns through roots, stubble, slough off roots nodules and root exudates or by artificial application in the form of organic manures which can otherwise be called organic fertilizers. The need to use renewable forms of energy and reduce costs of fertilizing crops has revived the use of organic fertilizers worldwide. Improvement of environmental conditions and public health important reasons for advocating increased use of organic materials. The increasingly demand of chicken meat in Sudan has prompted more poultry farming with consequent

* Corresponding author:

naim17amn@yahoo.com (Ahmed M. El Naim)

Published online at http://journal.sapub.org/ijaf

Copyright (C) 2012 Scientific \& Academic Publishing. All Rights Reserved effects on increased utilization of organic wastes (e.g. chicken manure) as fertilizers. Organic wastes contain varying amounts of water, mineral nutrients, organic matter (Weil, 1996). While the use of organic wastes as manure has been in practice for centuries world-wide (Straub, 1977) and in the recent times (Gambara et al., 2002; López-Masquera et al., 2008), there still exists a need to assess the potential impacts of chicken manure on crop yield and in particular evaluating the critical application levels. Moreover, the need and utilization of chicken manure has overtaken the use of other animal manure, because of its high content of nitrogen, phosphorus and potassium (Schjegel, 1992). Similarly, organic wastes are also being advocated for by different environmental organizations world-wide to preserve the sustainability of agricultural systems. Furthermore, chicken manure is preferred amongst other animal wastes because of its high concentration of macro-nutrients (Warman, 1986; Duncan, 2005; Oagile and Namasiku, 2010). Chescheir et al. (1986) recorded increase in nitrogen levels from $40-60 \%$ and $17-38 \%$ with respect to control for Norfolk sandy soils and Cecil sandy loam soils, respectively following application of manure. In addition, application of chicken manure to soil enhances concentration of water soluble salts in soil. Plants absorb plant nutrients in the form of soluble salts, but excessive accumulation of soluble salts (or soil salinity) suppresses plant growth. Stephenson et al. (1990) reported the EC of chicken manure of about $11 \mathrm{dS} / \mathrm{m}$ in silt loam soils too high for salinity sensitive crops. The $\mathrm{pH}$ of dry chicken 
manure pellets was found to be 7.9, with most of the nutrients available in this environment (López-Masquera et al., 2008) while a decrease in the soil $\mathrm{pH}(<6.5)$ affects the availability of nutrients to plants (Warman, 1986). Forage production is necessary for livestock production since they from an essential diet for fattening centers, dairy animal, and poultry production. Forge crops from best combination with other crops and hence give maximum satisfaction to consumers and maximum profits to the farm operation. In Sudan, forage production is very important for livestock production due to the facts that the Sudan has a huge number of animal wealth. Overgrazing of natural pasture, expansion of rain-fed agriculture, wild fire and drought resulted in reduction of rangeland. Forage production which provides almost $74 \%$ of the total annual livestock feed requirement. For the improvement of seasonal livestock feed balance the government comprehensive 25 years strategy (2002-2027) is intended to increase the green forage production from 4 million tons/year to almost 9 million tons by year 2027. The main cereal forage crops under irrigation in the Sudan are (Sorghum bicolor (L.), Moench) locally known as "Abusabien" Sudan grass (S. sudanense), the hybrid pioneer (Sorghum bicolor XS. sudanense) and recently maize (Zea mays L.) The selected forage crop in this study was Sorghum bicolor (L.), Moench. It is a member of the family Poaceae, the tribe is Andropogonae (Dogget, 1970). The variety under treatments is locally called forage in the Sudan for considered as a main cereal forage crop in the Sudan for the following reasons:-

Sorghum forage (Abu70) in general is quite resistant to drought and is well adapted to regions of limited rainfall e.g. Nile state, Northern state and Khartoum state under irrigation.

Sorghum forage is produced successfully on all types of soil and is more tolerant to salinity and alkalinity.

Sorghum forage dry matter production is greater compared to other fodder crops.

The feed is more palatable with less prussic acid.

Sorghum silage production per unit area is usually one to two-thirds higher than from corn.

Sorghum in some areas cut for hay and put up in large piles during the dry season of the year and later stacked. Recent studies are focused on improving sorghum forage quality and quantity. Organic matter is present in soil in comparatively small quantities with exception of peaty soil. Organic matter functions as a source of plant nutrients through its decomposition and release of adsorbed cations. There are few studies on utilization of chicken manure in fodder sorghum crop production, and information about effects on growth and yield in Sudan is scarce. Thus the main objectives of this study are to investigate the effect of fertilizer uptake on growth and yield of Abusabien, to compare different rates of chicken manure on growth and yield of fodder sorghum (Abu70) and to determinate the optimum rate of chicken manure which would give the maximum yield of forage

\section{Materials and Methods}

\subsection{General Description of the Experimental Site}

A field experiment was carried out during the period (February - May, 2007) in the Demonstration Farm of the Faculty of Agriculture, University of Khartoum in Shambat, Sudan. To study the effect of different rates of chicken manure on growth and forage yield of sorghum (Abu Sabein). The site is located in the semi-desert zone, (latitude 15040 $\mathrm{N}$, longitude 320 34-E and altitude 280 meters above sea level). The soil of the experiment site is alkaline ( $\mathrm{PH} \mathrm{8.0),}$ cracking clay with about $50 \%$ clay content. It contains about $0.065 \%$ Nitrogen $(\mathrm{N}) 0.230 \mathrm{Meq} / \mathrm{L}$ Potassium $(\mathrm{K})$ and $0.193 \mathrm{Meq} / \mathrm{L}$ viable Phosphorus $(\mathrm{P})$. The annual rainfall is about 100-200 $\mathrm{mm}$ and maximum temperature about $420 \mathrm{C}$ in summer and around $120 \mathrm{C}$ minimum temperature in winter (El Naim and Ahmed, 2010)

\subsection{Land Preparation}

The experimental site was disc ploughed, disc harrowed to crush clods and levelled out to maintain a well levelled seed bed and then followed by ridging up to $0.7 \mathrm{~m}$ between ridges which were oriented in a north-south direction. Individual plot size was $4 \times 5$ meters consisting of 6 ridges of 4 meters in length. In each plot, 2nd and 5th ridges were used for sampling.

\subsection{Treatments and Design}

The treatments in this study consisted of four levels of chicken manure $(0,1.2,2.5$ and 5.0 tons/ha.), designated as $\mathrm{C}_{0}, \mathrm{C}_{1}, \mathrm{C}_{2}$ and $\mathrm{C}_{3}$ respectively. The treatments were arranged in a Randomized Complete Block Design with four replications.

\subsection{Cultural Practices}

\subsubsection{Fertilization}

The type of manure used was chicken manure, which was collected from a poultry farm in Shambat. The fertilizer was applied on 1/2/2007 broadcasted manually on the bottom of the ridges mixed with soil and distributed equally to the entire plot using a hand hoe and then irrigated immediately.

\subsubsection{Sowing Date and Seeding Rate}

Sowing was done manually on one side of the ridge (eastern side of ridge) and it was carried out on February, $11^{\text {th }}$. The seed rate applied was $20 \mathrm{Kg} / \mathrm{fed}$.

\subsubsection{Irrigation}

Irrigation was applied immediately after seeding the plots; irrigation was applied on a weekly interval.

\subsubsection{Weeding}

Weeding was practiced one time during the growing period 30 days from sowing. 


\subsection{Character Studies}

The following parameters were measured during the study period.

1. Plant population (plant density); An area of one-meter row $\left(0.7 \mathrm{~m}^{2}\right)$ was permanently marked in each treatment in one of the two middle ridges. Plants were counted after 7,21 days from sowing, and at harvest.

2. Plant height $(\mathrm{cm})$ : Ten plants were randomly selected from the $2^{\text {nd }}$ and $5^{\text {th }}$ ridges of each individual plot and the plants were tagged. The height of the plant was measured from the ten plants was recorded in $(\mathrm{cm})$. Plant height was measured after 30,60, days from planting, and at harvest.

3. Number of leaves per plant: This parameter was measured by calculating all leaves of ten randomly selected plants after 30, 60 days from sowing and at harvest. The mean number of leaves per plant was recorded.

4. Stem diameter $(\mathrm{cm})$ : Measured by using a vernier (caliper) from the middle of the $2^{\text {nd }}$ inter-node of ten plants selected randomly from the $2^{\text {nd }} 5^{\text {th }}$ ridges of each plot and the mean stem diameter were calculated.

5. Leaf area $\left(\mathrm{cm}^{2}\right)$ : Ten plants were chosen randomly from $2^{\text {nd }}$ and $5^{\text {th }}$ ridges and the leaf area of the fourth leaf from the top was measured following the Stickler method (1961) using the following formula: leaf area (LA) $=$ length $\times$ maximum width $\times 0.75$.

6. Leaf area index (LAI): Leaf area index (L.A.I), a dimensionless quantity, is the leaf area (upper side only) per unit area of soil below. It is expressed as $\mathrm{m}^{2}$ leaf area per $\mathrm{m}^{2}$ ground area. Leaf area index was measured at the fourth week from sowing and at the harvest using the following formula:

\section{$\mathrm{LAI}=\underline{\text { Leaf area per plant }}$ \\ Plant ground area}

7. Fresh weigh: First and second cuts of the green forage of the one meter row $\left(0.7 \mathrm{~m}^{2}\right)$ was chosen from one ridge as destructive samples and cut after 30, 60 days from sowing. At the harvest the whole plot for each treatment was clipped, weighed using a spring balance immediately in the field to get the fresh weight. A sickle was used for clipping plants $5-10 \mathrm{~cm}$ above the soil surface. Final fresh yield was calculated in tons per hectare.

8. Dry weight: The green forage of the one meter row $\left(0.7 \mathrm{~m}^{2}\right)$ was left to dry in an oven until a constant weight was reached then final dry matter yield was calculated in tons per hectare.

\subsection{Statistical Analysis}

The collected data were analyzed according to the statistical procedure described by Gomez and Gomez (1984) and the computer package MSTAT-C. Means were separated using the LSD procedure.

\section{Results and Discussion}

\subsection{Growth Attributes}

The results of growth attributes (plant density, plant height, stem diameter, number of leaves per plant and leaf area index (LAI)) are shown in Tables 1, 2, 3, 4 and 5 respectively. The chicken manure significantly affected growth attributes. Increased rate of chicken manures increased plant height, stem diameter, number of leaves per plant and leaf area index of forage sorghum. The maximum plant height, number of leaves per plant and leaf area index was recorded under the highest rate. The high rate of chicken manure ( 5 ton/ha) applied increase the plant height by about $36 \%$

Table 1. Effect of chicken manure on plant population at different counts during the growing period

\begin{tabular}{|c|c|c|c|}
\hline Treatments & $\begin{array}{c}1^{\text {st }} \text { count at } 7 \\
\text { days }\end{array}$ & $\begin{array}{c}2^{\text {nd }} \text { count at } 21 \\
\text { days }\end{array}$ & $\begin{array}{c}3^{\text {rd }} \text { count at } \\
\text { harvest }\end{array}$ \\
\hline $\mathrm{C}_{0}$ & 32.25 & 35.25 & 30.50 \\
\hline $\mathrm{C}_{1}$ & 38.75 & 42.00 & 36.25 \\
\hline $\mathrm{C}_{2}$ & 43.00 & 46.50 & 40.50 \\
\hline $\mathrm{C}_{3}$ & 50.00 & 54.75 & 48.50 \\
\hline $\mathrm{LSD}$ & 3.63 & 5.58 & 3.58 \\
\hline $\mathrm{CV} \%$ & 5.51 & 3.64 & 5.75 \\
\hline $\mathrm{SE} \pm$ & 0.80 & 0.57 & 0.79 \\
\hline
\end{tabular}

Table 2. Effect of chicken manure on plant height $(\mathrm{cm})$ at different samplings during the growing period

\begin{tabular}{|c|c|c|c|}
\hline Treatments & $\begin{array}{c}1^{\text {st }} \text { sampling at } \\
30 \text { days }\end{array}$ & $\begin{array}{c}2^{\text {nd }} \text { sampling at } \\
60 \text { days }\end{array}$ & $\begin{array}{c}3^{\text {rd }} \text { sampling at } \\
\text { harvest }\end{array}$ \\
\hline $\mathrm{C}_{0}$ & 24.99 & 104.85 & 117.94 \\
\hline $\mathrm{C}_{1}$ & 26.39 & 116.96 & 138.43 \\
\hline $\mathrm{C}_{2}$ & 30.60 & 124.77 & 151.05 \\
\hline $\mathrm{C}_{3}$ & 35.33 & 131.44 & 161.26 \\
\hline $\mathrm{LSD}$ & 5.76 & 33.62 & 16.13 \\
\hline $\mathrm{CV} \%$ & 12.27 & 17.59 & 7.09 \\
\hline $\mathrm{SE} \pm$ & 1.27 & 7.43 & 3.57 \\
\hline
\end{tabular}

Table 3. Effect of chicken manure on stem diameter $(\mathrm{cm})$ at different counts during the growing period

\begin{tabular}{|c|c|c|c|}
\hline Treatments & $\begin{array}{c}1^{\text {st }} \text { sampling at } \\
30 \text { days }\end{array}$ & $\begin{array}{c}2^{\text {nd }} \text { sampling at } \\
60 \text { days }\end{array}$ & $\begin{array}{c}3^{\text {rd }} \text { sampling at } \\
\text { harvest }\end{array}$ \\
\hline $\mathrm{C}_{0}$ & 0.39 & 0.81 & 1.01 \\
\hline $\mathrm{C}_{1}$ & 0.44 & 0.84 & 0.99 \\
\hline $\mathrm{C}_{2}$ & 0.43 & 0.84 & 0.91 \\
\hline $\mathrm{C}_{3}$ & 0.44 & 0.83 & 0.92 \\
\hline $\mathrm{LSD}$ & 0.09 & 0.20 & 0.38 \\
\hline $\mathrm{CV} \%$ & 13.95 & 13.77 & 23.22 \\
\hline $\mathrm{SE} \pm$ & 0.02 & 0.04 & 0.07 \\
\hline
\end{tabular}

Table 4. Effect of chicken manure on number of leaves/plant at different counts during the growing period

\begin{tabular}{|c|c|c|c|}
\hline Treatments & $\begin{array}{c}1^{\text {st }} \text { count at } 30 \\
\text { days }\end{array}$ & $\begin{array}{c}2^{\text {nd }} \text { count at } 60 \\
\text { days }\end{array}$ & $\begin{array}{c}3^{\text {rd }} \text { count at } \\
\text { harvest }\end{array}$ \\
\hline $\mathrm{C}_{0}$ & 6.28 & 9.05 & 9.25 \\
\hline $\mathrm{C}_{1}$ & 7.18 & 9.47 & 10.25 \\
\hline $\mathrm{C}_{2}$ & 7.20 & 9.92 & 10.7 \\
\hline $\mathrm{C}_{3}$ & 7.33 & 10.63 & 11.07 \\
\hline $\mathrm{LSD}$ & 1.49 & 3.25 & 1.28 \\
\hline $\mathrm{CV} \%$ & 27.61 & 11.57 & 7.75 \\
\hline $\mathrm{SE} \pm$ & 0.68 & 0.40 & 0.28 \\
\hline
\end{tabular}


Table 5. Effect of chicken manure on LAI at different samplings during the growing period

\begin{tabular}{|c|c|c|}
\hline Treatments & $1^{\text {st }}$ sampling at 30 days & at harvest \\
\hline $\mathrm{C}_{0}$ & 2.58 & 10.09 \\
\hline $\mathrm{C}_{1}$ & 4.07 & 14.64 \\
\hline $\mathrm{C}_{2}$ & 5.38 & 15.26 \\
\hline $\mathrm{C}_{3}$ & 5.57 & 17.60 \\
\hline $\mathrm{LSD}$ & 2.19 & 4.44 \\
\hline $\mathrm{CV} \%$ & 31.09 & 19.28 \\
\hline $\mathrm{SE}^{ \pm}$ & 0.48 & 0.98 \\
\hline
\end{tabular}

The results showed that there were significant differences among treatments in most parameters during the growing period for growth attributes under study.

Chicken manure treatments gave taller plants, higher number of leaves per plant and increasing the yield of fresh and dry matter compared to the control. These responses may refer to its high content of nitrogen, phosphorus and potassium (Schjegel, 1992). fertilization suggest that this crop as it is non - leguminous, might have obtained high supply of nitrogen from the soil directly. Another explanation may by due to the effect of chicken manure on soil fertility (chicken manure restored soil fertility). This is in agreement with that of Bendfeldt, (2002) who reported that potential uses for poultry manure as a fertilizer and soil amendment. On the other hand, Mullins (2002) reported that poultry litter contains, a considerable amount of organic matter, hence have an impact on soil $\mathrm{pH}$ and liming due to varying amount of calcium carbonate in poultry feed. Elamin (1991) found that organic matter decomposition improved the physical and chemical proprieties of the soil.

The source of nitrogen from poultry manure resulted in taller plants because nitrogen was found to increase number of nodes as well as inter node length and consequently plant height. Chicken manure $\mathrm{C}_{3}$ (5 ton/ha), gave taller plants than the control. This is agreement with that Hassan, (2002) who reported that chicken manure fertilizer significantly increased plant height. Higher rate of chicken manure ( 5 ton/ha) significantly increased a number of growth attributes of forage sorghum cultivar (Abusabien), than the control. On the other hand, this agreed with Eltahir (1998) who reported that manure alone or mixed with the urea resulted in an increase in growth attributes as well as forage yield of two forage maize cultivars than the control. All the fertilized plots gave higher leaf number per plant than the control, with higher value for the highest chicken manure doze (5 ton chicken manure/ha).

It is obvious that in our study the number of plants per unit area were increased with time but the number declined by third count. This may be attributing to fact that mortality of plant with time due to competition between plants for growth requirements and hence only stronger ones can survive.

\subsection{Forage Yield}

The results of forage yield (fresh and dry) as affected by chicken manure are representing in Table 6 and 7. Forage yield is always related to growth parameters. All treatment had significant effect on fodder yield (fresh and dry), compared to the control. Fertilization generally increased forage yield during the growing period. Chicken manure resulted in an increase in growth attributes as well as forage yield. Chicken manure $\mathrm{C}_{3}$ ( 5 ton/ha) produced higher fresh and dry forage at harvest than the control. This is in agreement with Hassan(2002) who found that the highest yield of both $\mathrm{Abu}$ Sabien and pioneer 988 was obtained with (7.5 tons/fed) chicken manure treatment while the lowest yield was obtained with the (control). On the other hand, two maize cultivars gave higher fresh and dry matter yield under condition of urea alone or mixed with farmyard manure as reported by Eltahir (1998). This result was expected since chicken manure contains nitrogen that positively increased growth .Abu suwar and El Zalal (2010) reported that Chicken manure rates significantly affected forage fresh and dry yields. They found that as the rate of manure increased both fresh and dry yields increased. The maximum fresh forage and dry matter produced were recorded under the highest rate of manure applied. Several researchers ( Magid et al, 1998; Postma et al, 1998; Hue, Sobieszczyk, 1999 and Abusuwar and El Zalal, 2010) reported that nitrogen and phosphorus uptake, as a function of chicken manure application rate, increased progressively with increasing manure rates.

Table 6. Effect of chicken manure on forage fresh yield (ton/ha) at different counts during the growing period

\begin{tabular}{|c|c|c|c|}
\hline Treatments & $\begin{array}{c}1^{\text {st }} \text { sampling at } \\
30 \text { days }\end{array}$ & $\begin{array}{c}2^{\text {nd }} \text { sampling at } \\
60 \text { days }\end{array}$ & at harvest \\
\hline $\mathrm{C}_{0}$ & 3.13 & 7.16 & 9.56 \\
\hline $\mathrm{C}_{1}$ & 4.15 & 9.16 & 12.13 \\
\hline $\mathrm{C}_{2}$ & 4.95 & 10.13 & 15.03 \\
\hline $\mathrm{C}_{3}$ & 6.60 & 13.11 & 19.50 \\
\hline $\mathrm{LSD}$ & 0.77 & 1.45 & 1.66 \\
\hline $\mathrm{CV} \%$ & 10.19 & 9.16 & 7.38 \\
\hline $\mathrm{SE}{ }^{ \pm}$ & 0.17 & 0.32 & 0.37 \\
\hline
\end{tabular}

Table 7. Effect of chicken manure on forage dry yield (ton/ha) at different counts during the growing period

\begin{tabular}{|c|c|c|c|}
\hline Treatments & $\begin{array}{c}1^{\text {st }} \text { sampling at } \\
30 \text { days }\end{array}$ & $\begin{array}{c}2^{\text {nd }} \text { sampling at } \\
60 \text { days }\end{array}$ & at harvest \\
\hline $\mathrm{C}_{0}$ & 1.69 & 2.21 & 3.76 \\
\hline $\mathrm{C}_{1}$ & 1.90 & 2.56 & 4.76 \\
\hline $\mathrm{C}_{2}$ & 2.72 & 3.18 & 6.13 \\
\hline $\mathrm{C}_{3}$ & 3.20 & 5.63 & 8.66 \\
\hline $\mathrm{LSD}$ & 0.82 & 0.74 & 0.86 \\
\hline $\mathrm{CV} \%$ & 21.44 & 13.57 & 9.24 \\
\hline $\mathrm{SE} \pm$ & 0.18 & 0.16 & 0.19 \\
\hline
\end{tabular}

\section{Conclusions}

Chicken manure resulted in an increase in growth attributes as well as forage yield. Chicken manure (5.0 ton/ha) produced higher fresh and dry forage at harvest than the 
control.

\section{REFERENCES}

[1] Abusuwar, A. O. and El Zalal, H. A. (2010). Effect of chicken manure on yield, quality and HCN concentration of two forage Sorghum (Sorghum bicolor (L) Moench) cultivars. Agric. Biol. J. N. Am., 1(1): 27-31

[2] Agboola AA, Omueti JA (1982). Soil Fertility Problem and Its Management In Tropical Africa. Paper presented at the International Institute of Tropical Agriculture Ibadan, Nigeria. p. 25

[3] Ayoola, O. T. and O. N. Adeniyan (2008). Influence of poultry manure and NPK fertilizer on yield and yield components of crops under different cropping systems in south west Nigeria. African Journal of Biotechnology.5 (15), 1386-1392

[4] Bendfeldt (2002). Poultry litter as fertilizer and soil Amendment. Associate Extension Agent, Agricultural and Natural Research, R.A. Clark, Extension agent, Agriculture and natural resources

[5] Chescheir PW, Westserman LM, Safley Jr LM (1986). Laboratory methods for estimating available nitrogen in manures and sludges.Agric. Wastes 18: 175-195

[6] Duncan J (2005). Composting chicken manure. WSU Cooperative Extension, King County Master Gardener and Cooperative Extension Livestock Advisor

[7] Elamin, E.E. (1991). Effect of Organic Manure Decomposition on Some Soil Properties. M.Sc (Agric). Thesis,Faculty of Agriculture, University of Khartoum

[8] El Awad, G.A.(2004). Effect of chicken manure and urea fertilizer on growth and yield of Teff Grass. M.Sc. Thesis. University of Khartoum, Faculty of Agriculture, Sudan

[9] El Naim, A. M and Ahmed, M, F (2010). Effect of irrigation on consumptive use, water use efficiency and crop factor of sesame (sesamum indicum. L.). Journal of Agricultural Extension and Rural development. 2(4): 58-65

[10] Gambara P, Machemedze T, Mwenye D (2000). Chihota soil fertility Project, Annual Report 1998 to 1999. Unpublished report, AGRITEX, Marondera Zimbabwe

[11] Gomez,K.A. and A.A Gomez(1984).Randomized Complete Block Design In: Statistical Procedure for Agricultural Research. John Willey and Sons. New York U.S.A

[12] Hassan,E.A.H.(2002).Effect of chicken manure and season on the performance and HCN Content of two Forage sorghum cultivar, Ph.D. Thesis, Faculty of Agriculture, University of
Khartoum, Sudan

[13] Hue, N.V. and Sobieszczyk, B.A..(1999). Nutritional values of some bio-wastes as soil amendments. Compost Sci. Utilization 7:34-41. CAB Abstracts, 98/2000

[14] López- Masquera ME, Cabaleiro F, Sainz MS, López- Fabal A, Carral E (2008). Fertilizing value of broiler litter: Effects of drying and pelletizing. Bioresource Technol. 99: $5626-5633$

[15] Magid, H.M., Abdel Al, S.I.;Rabie, R.K. and Sabra R.E. (1998). Chicken manure as a bio-fertilizer for Wheat Gown in Sandy Soils of Saudi Arabia. Egyption J. Soil Sci. 38:329-338

[16] Mullins, L.G. (2002). Poultry litter as afertilizer and soil amendment. Crop and soil Environmental science and ES, Bendfeldt associate extension agents Agricultural and natural resources R.A. Clark Extension Agent, Agriculture and Natural Resources, Virginia Tech. Publication number 424-534 posted January 2002

[17] Oagile D and Namasiku M (2010). Chicken manure-enhanced soil fertility and productivity: Effects of application rates. Journal of Soil Science and Environmental Management.1(3) 46-54

[18] Obi ME, Ebo PO (1995). The effect of different management practices on the soil physical properties and maize production in severely degraded soil in southern Nigeria. Biological Resource technology. pp. 51: 117-123

[19] Ojeniyi SO (2000) .Effect of goat manure on soil nutrients and okra yield in a rain forest area of Nigeria. Applied Tropical Agriculture 5:20-23

[20] Postma, R.; Erp, P.V. and Van, E.P. (1998). Nutrient management in arable farming and outdoor vegetable growing. Mestoto Hen, 13-19. CAB Abstract 1998/99

[21] .Schjegel AJ (1992). Effect of composted manure on soil chemical properties and nitrogen use by grain sorghum. J. Prod. Agric. 5: 153-157

[22] Stephenson AH, McCaskey AT, Ruffin BG (1990). A Survey of broiler litter composition and potential value as a nutrient resource. Biol.Wastes, 34: 1-9

[23] Stickler, F.C., Wearden, S. and Pouli W. (1961). Leaf area determination in grain Sorghum. Agron. J. 53: 187-189

[24] Straub D (1977). A hot issue-chicken manure. Tilth producers quarterly A Journal of Organic and Sustainable Agriculture. United States

[25] Warman PR (1986). The effect of fertilizer, chicken manure and dairy manure on Timothy yield, tissue composition and soil fertility. Agric.Wastes 18: 289-298 